\title{
Exploring Collaborative Design and Sustainable Living in British Cohousing Communities
}

\author{
Jingjing Wang, Yiru Pan, Karim Hadjri \\ School of Architecture, \\ The University of Sheffield, UK \\ jwang130@sheffield.ac.uk, ypan13@sheffield.ac.uk, k.hadjri@sheffield.ac.uk
}

\begin{abstract}
Cohousing is a new collaborative housing concept to foster closer social bonding and sustainable communities. This paper discusses the key principles, priorities, and challenges of Cohousing design through interviews with four architects and four Cohousing community residents. The interviews were carried out 1) to demonstrate the application of the design standards, 2) to understand residents' thinking and behaviour change, and 3) to establish the environmental and social sustainability in a cohousing setting. The findings could lead to a toolkit and guide for Cohousing design process and to establish a better understanding of Cohousing design and development process in the UK.
\end{abstract}

Keywords: Cohousing Community; Cohousing Design; Environmental Sustainability; Social Sustainability;

eISSN 2398-4295 @ 2018. The Authors. Published for AMER ABRA cE-Bs by e-International Publishing House, Ltd., UK. This is an open-access article under the CC BY-NC-ND license (http://creativecommons.org/licenses/bync-nd/4.0/). Peer-review under responsibility of AMER (Association of Malaysian Environment-Behaviour Researchers), ABRA (Association of Behavioural Researchers on Asians) and CE-Bs (Centre for EnvironmentBehaviour Studies), Faculty of Architecture, Planning \& Surveying, Universiti Teknologi MARA, Malaysia.

http://dx.doi.org/10.21834/ajbes.v3i14.163 


\subsection{Introduction}

Traditional forms of housing no longer address the needs of many people (McCamant \& Durrett, 1994). A lot of people are mis-housed, ill-housed or unhoused because of the lack of adequate housing options (McCamant \& Durrett, 1994). The term 'Cohousing' is derived from the phrase 'co-operative housing'. It is a creative housing model, which could offer an alternative solution to the housing crisis (Priest, 2015; Wang et al., 2016). Typical Cohousing communities have between 15 to 35 families, about 50 to100 people (Lietaert, 2009). Cohousing residents are involved in the design and planning processes (Berggren, 2016; Lietaert, 2009; Ruiu, 2016). In other words, residents manage the whole community with the help from experts (developers, architects, facilitators). It is a new collaborative housing concept designed to foster meaningful relationships, closer social bonding and green living (Wang et al., 2016). The research aims to discuss the key principles, priorities, and challenges of the Cohousing design process through interviews with four architects and four Cohousing residents. This paper explores Cohousing theories influencing architectural design languages and Cohousing community social interactions within the UK context.

\section{0 Literature Review}

\subsection{What is Cohousing?}

The Cohousing concept emerged in Denmark. The concept spread rapidly and reached the Netherlands, where the first Cohousing community was completed in 1977. "The original Cohousing was designed for two main purposes: to increase the quality of Cohousers' life and to lessen the burden of everyday life, while increasing free-time at home" (Lietaert, 2009, p.578). Its concept is also well established in Sweden, Germany, the UK and the US.

Cohousing is a new type of urban or semi-urban housing model (Canadian Cohousing Network, 2018; Lietaert, 2009), where residents are committed to living together as a community and gain the benefit of a supportive social network (Garciano, 2011). In the UK context, Cohousing models can be described as being two types: a) The intergenerational community where older people and families live side by side, such as Lancaster cohousing; b) The peer-group community where a range of people over 50 prefer to live in a child-free environment, such as The Older Women's Cohousing Company in London (Housing LIN, 2008, p.5). According to Lietaert (2009), there are six key features to define a Cohousing community:

1) Participatory process

2) Intentional neighbourhood design

3) Extensive common facilities

4) Complete resident management

5) Absence of hierarchy

6) Separated incomes

Cohousing communities are neighbourhood developments where private and common facilities are combined in response to the social and the practical needs of contemporary urban citizens (Lietaert, 2009, p.577). Cohousing residents organize and participate in the 
planning and design process for the community development and make decisions collectively through consensus.

\subsubsection{Physical Design}

In a Cohousing community, each household has their own front door. Homes are grouped, facing the common spaces. This offers access for everyone to the open areas and the chance to socialise with neighbours under 'casual surveillance' (Berggren, 2017; Ruiu, 2014). The common house is one of the key features of a Cohousing community, which includes a shared kitchen and dining area, common laundry and guest rooms, and sometimes a workshop, children's play area, a shop, and a library (Berggren, 2017). McCamant and Durrett (1994) point out that extensive common facilities are an integral part of the community, and common areas are designed for daily use to supplement private living areas. The physical design and community layout aim to encourage a strong sense of home and also creates the sense of belonging to the community.

\subsubsection{Social Design}

Cohousing residents commit to the concept, contribute to the community and also share resources, spaces, tools, time, ideas and skills. There are four fundamental characteristics of a cohousing social setting: 1) weekly shared meals; 2) regular membership meetings; 3 ) resources sharing; 4) diverse membership (e.g., age, religion and household type) (Berggren, 2017; Jarvis, et al., 2016; Sargisson, 2012;). In some respects, Cohousing is not an entirely new concept. In the past, most people lived in a village or closely-knit neighbourhood, such as a commune. However, a Cohousing community is not a commune, and it offers a contemporary approach for re-creating the sense of community and neighbourhood while responding to today's needs for a less constraining environment (McCamant \& Durrett, 1994). There are obvious practical advantages by living in a Cohousing community, such as a vibrant social atmosphere, reduced loneliness, supportive child and care for older people, and sustainable living.

\subsubsection{Social Sustainability}

When discussing the social aspects in sustainable cohousing community, it is essential to understand the term 'social sustainability', because social benefit is one of the main aims to develop cohousing community- provide closer relationship with community members and also gain strong sense of community, belonging and mutual support (Fromm,2000 \& Garciano, 2011). There three aspects of defining the field 'sustainability': environmental, social and economic sustainability perspectives (Lehtonen, 2004). There is limited literature that specifically focuses on social sustainability. However, broader literature is available on the overlapping concepts such as social capital, social cohesion, social interaction, social networks and social inclusion (Dempsey, 2009). More precisely, social cohesion and inclusion are claimed in the theory and policy to contribute to strong, fair and just societies for present and future communities (Lister, 2000). According to Dempsey (2009, p293), "Sustainability of community involves social interaction between community members; the relative stability of the community, both in terms of overall maintenance of numbers/ balance 
(net migration) and of the turnover of individual members; the existence of, and participation in, local collective institutions, formal and informal; levels of trust across the community, including issues of security from threats; and a positive sense of identification with, and pride in, the community."

Another definition can be found from The Young Foundation (2010), social sustainability can be seen as a process to promote a successful place for the wellbeing, by understanding people's needs and the place they live and work. The social sustainability is related to the physical design and the social context within a place, such as cultural life, social networks and citizen engagement. Cohousing provides a valuable case study for analysis because it uses its design factors and social structure to encourage social interaction in the neighbourhood. Furthermore, Cohousing offers a unique opportunity to study different variables, such as formal and informal social factors, personal factors and design factors (Williams, 2005). In cohousing context, social sustainability can be addressed through various aspects, such as residents' social interaction and common activities, resident participation, sharing, use of common spaces, size of the community and living unit, etc.

\subsection{Current Cohousing Communities in the UK}

The origin of British Cohousing started by the end of the 1990s. With the development of the housing market over the past two decades, there are 19 built communities all over the country, and more than 60 Cohousing groups are in progress (UK Cohousing Network, 2018; Morrison, 2013). A growing number of housing practitioners, funders and policy-makers have started to consider Cohousing as an ideal and realisable model for sustainable and affordable housing development (Garciano, 2011). At the moment, there are diverse types of Cohousing around the UK, such as low impact affordable Cohousing (LILAC), Cohousing for older people (Older Women Cohousing), Eco-village (Cambridge Community Land Trust), Vegetarian cohousing (Veganic Cohousing), etc.

In England, Cohousing groups have been working with DCLG (Department for Communities and Local Government) to ensure the New Community Housing Fund is available to Cohousing Groups. In Wales, Cohousing has contributed to the Welsh Government Expert Group in response to an ageing population. Cohousing has been recognised as an important role in the widening choice of housing options. Hence, financial and professional support and advice should become available to facilitate community-led housing solutions. In Scotland, Age, Home and Community: A Strategy for Housing for Scotland's Older People: 2012 - 2021 was published by the Scottish Government in 2011. This document points out that the Scottish Government is keen to encourage the development of new and innovative models of housing that enable older people to maintain their independence in the community. Additionally, Northern Ireland has an active intergenerational Cohousing group, who are promoting Cohousing in the country (UK Cohousing Network, 2018). 


\subsection{The Cohousing Approach to 'Lifetime Homes'}

\subsubsection{Lifetime Home Standards}

Lifetime Home Standards were established in the mid-1990s to incorporate a set of principles that should be implicit in good housing design (The Lifetime Home Design Guide, 2010). It includes sixteen design criteria under five principles (Inclusivity, Accessibility, Adaptability, Sustainability and Good Value) that can be widely applied to new homes and housing retrofit. Lifetime Homes can provide benefits especially to older people, disabled people and anyone with a physical impairment to make their home more accessible and inclusive. The sixteen design criteria were used to improve the property's convenience for a wide range of people and also introduce the flexibility and adaptability into the housing layout, housing outdoor spaces and interior design. By bringing Lifetime Home design into mainstream housing this will allow older people to stay at their home for longer and postpone/reduce the need for expensive home adaptation. Also, it will benefit disabled people to achieve independent living due to accessible housing design. However, limited literature is available as evidence for the inclusion of Lifetime Home Standards into Cohousing models. It is more challenging to use these design standards for Cohousing models compared with mainstream housing due to the complexity and variety of the Cohousing community design and its operating model. A detailed discussion about the advantages and disadvantages of the Lifetime Home Standard application in Cohousing community is presented in the following sections.

\subsubsection{Lifetime Home Standards and Cohousing Models}

In a Cohousing context, Lifetime Homes Standards can be applied to benefit both types of Cohousing models. Therefore, Lifetime Cohousing could become an effective housing model to maximise the opportunities and potentials of housing and community design for Cohousing members and promote better neighbourhood sustainability. In addition, Lifetime Homes can also affect social interaction and activities, as Kelly (2001, p.72) suggested, "flexible, usable and adaptive building design of lifetime homes is able to influence social patterns and processes. It will encourage neighbourhoods to evolve and flourish [...] they represent the best way to achieve community sustainability." Despite the many advantages of Lifetime Home Standards, there are also some limits to be considered. On the one hand, within the sixteen design criteria, Lifetime Home Standards do not incorporate sensory factors, such as temperature, humidity, air quality, sound insulation, lighting control. On the other, the design criteria cannot be fully applied in multi-generational families, because they exclude children from the design requirements (Allen et al., 2002; Imrie, 2006). Due to these limitations and the specificity of the Cohousing model, local authorities will need to be willing to modify some standard domains for tenancies and agree a better way and criteria to meet a Cohousing group's needs. The research presented in this paper will address these challenges and evaluate the role of lifetime Cohousing.

\subsection{Cohousing Design Considerations}

The participatory process initially creates a sense of belonging and sense of community amongst Cohousing members, the design of the physical environment that supports and 
shapes residents social life and daily routine. The environment can promote or discourage interaction between people, resulting in either a lively or lifeless place (McCamant \& Durrett,1994, p.173). McCamant and Durrett (1994) address these important design considerations (environmental and social factors) from their research:

Table 1: Design Considerations

\begin{tabular}{|c|c|}
\hline -The site plan and community layout & Creating an intimate atmosphere \\
\hline Car-free living space & The design of private units \\
\hline A child-friendly environment & Choices of housing models \\
\hline $\begin{array}{l}\text { The transitional space between private and } \\
\text { common space }\end{array}$ & $\begin{array}{l}\text {-Transitions between community and surrounding } \\
\text { neighbourhood }\end{array}$ \\
\hline Location of the common house & Design of the common house \\
\hline Pedestrian circulation & $\begin{array}{l}\text {-Accommodating future changes (Flexible architecture } \\
\text { and Lifetime Homes) }\end{array}$ \\
\hline
\end{tabular}

(Source: McCamant \& Durrett, 1994)

\subsection{Methodology}

This research aims to examine the key principles, priorities and challenges from the architectural perspective, also, to explore how Cohousing community design affects residents' attitudes, behaviour and daily living. A qualitative approach (interview) has been used in this study. Why have qualitative approaches been chosen? Firstly, this approach works well to understand people's lives, lived experiences, behaviours, emotions, and feelings as well as social movements, cultural phenomena, and interactions between nations (Strauss \& Corbin, 1998). Secondly, it is about the nature of the research problem. This approach offers more opportunities to explore the differences and similarities of people's lives and to find out the actions and thoughts of people (Strauss \& Corbin, 1998). Finally, qualitative methods can be applied to explore the research area which little is known or about which much is known to gain unique understanding (Stern, 1980). In sum, qualitative approaches are the most suitable way to conduct this study.

The strength of qualitative interviewing is precisely its capacity to access self-reflexivity among interview subjects, leading to gather likelihood of the telling of collective stories: respondents may reveal feelings, beliefs, and private doubts that contradict or conflict with 'what everyone thinks' (Silverman, 2016, p.130). The limitations of the methodology can be found: firstly, if the sample size is small, the answers of interviews could present particular opinions in the chosen communities; other possibilities and ideas might not be mentioned. Secondly, the interview method through telephone has been used for some participants,and it cannot capture the interviewees' body language and expression. The methodology will use a qualitative approach through interviews with four cohousing project architects and four 
residents. The literature review will inform the questions that will be explored. The research method and process are presented in the following flowchart (Fig.1).

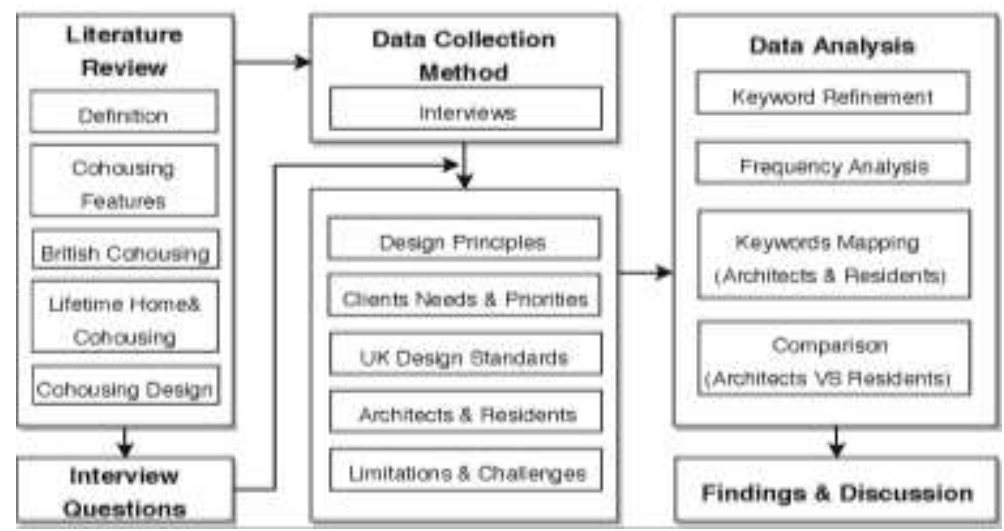

Fig 1: Research Process Flowchart

(Source: authors)

\subsection{Data Collection}

This study aims to discuss the key principles, priorities and challenges of the Cohousing design process through semi-structured interviews with four Cohousing project architects and four residents. These projects are located in Sheffield, Lancaster and Cambridge, with two being in Sheffield. Purposive and Snowball sampling methods were employed in this study (Petty, 2012). A few participants were selected according to relevance to study; after that, other interviewees were nominated by the initial participants.

Each interview lasted approximately for an hour and was held on-site or by telephone. The conversations were recorded with the participants' permission for further analysis. Additionally, the interview activity followed the University's ethics guide by using Participants Information Sheet (PIS) and Consent Form (CF). When the interviewee could not sign the consent form by hand, oral consent was used instead. Eleven open-ended interview questions were carried out to target six aspects of the cohousing community, which are:

1) Motivations

2) Sustainable/community living

3) Residents social interaction

4) Options for older people

5) Affordability

6) Design principles and standards

The questions are listed below:

\section{A. Residents' Motivation}


What is your 'motivation' to create/ join a Cohousing community?

\section{B. Sustainable/ Community living}

How can a Cohousing scheme contribute to sustainable living and sustainable communities?

\section{Residents social interaction}

What motivates and sustains social interaction in cohousing?

How Cohousing community living affects your thinking and behaviour?

What are the criteria to select the new residents?

\section{Options for older people}

Do you think Cohousing is a good option for older people and contributes to multigenerational living?

\section{E. Affordability}

How can Cohousing be an affordable option for different social groups?

\section{F. Design principles and standards}

Could a Cohousing model fit into a Lifetime Home standard? Or other design standards applied?

Could you highlight the challenges during the design process?

What are the main (environmental) technologies applied in Cohousing communities?

The comparison of the private living area between Cohousing and their previous homes.

The data collection process followed the University's code of practice and guidelines on ethics and research governance. Participants' confidentiality and anonymity were maintained throughout the study.

\subsection{Data Analysis Strategy}

There are six steps for the data analysis (Fig. 2). The data analysis took audio interview recordings as the starting point, followed by the word to word data transcript. Then, the keywords for each interview question answered were coded manually. Next, the keywords were abstracted from each aspect. Afterwards, the calculation of key concept frequency aimed to show the core opinions, which were heavily repeated by the interviewees and how interviewees value these opinions (positive, neutral, negative). The keywords mapping was done according to the interview question categories. This step aims to visualise the details of the interview data. The final step was the views comparison (Table.2) between architects and cohousing residents. Their ideas have been compared towards each question category, which presents the view difference between the design stage and real community living. Table. 2 also illustrates some design factors which have been neglected by the architects, shows the new understanding of cohousing living and to identify what are the important drivers of the Cohousing design process. 


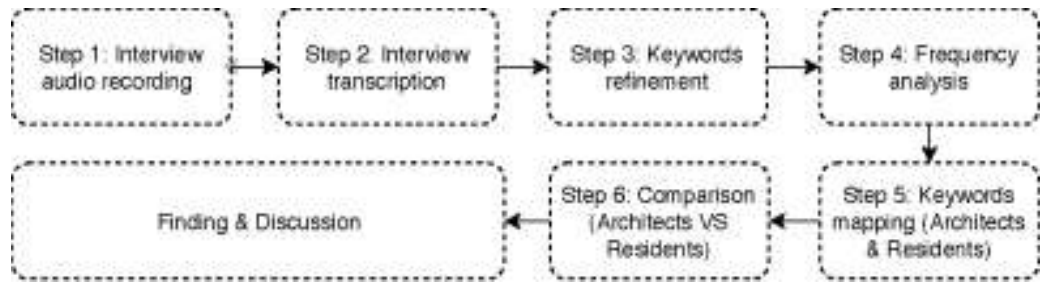

Fig.2: Data analysis

(Source: authors)

\subsection{Results}

The interview findings include four parts:

1) Key concepts abstracted from the interview answers (Fig.3- architects group , Fig.4residents group);

2) Keywords analysis: strengths and weakness analysis (Fig.5- architects group, Fig.6residents group);

3) Views Comparison (architects VS residents). (Table. 2);

4) List of British design standards and analysis (Table. 3).

Through the interviews, 'social aspect' and 'sustainable living' are the popular considerations to the residents' motivation. Shared resources, meals and community facilities are the key drivers which contribute to sustainable living. In addition, sharing also becomes the part of community identity to the whole group. The answers from the interviews also show that Cohousing could be a good living option for older people, it is able to provide the opportunity for multigenerational living and a sense of belonging and reduce loneliness. Moreover, the age-friendly design could be applied to the community as it plays an important role in the mobility and accessibility for older residents. Many design standards have been pointed out during the interview process, such as PassivHaus and Lifetime Home standards. However, there are various challenges to apply these standards to the common spaces and private units. For example, Lifetime Home standards require more circulation space; PassivHaus standard may need more investments from the beginning of the project. Therefore, Cohousing may become more expensive than the mainstream housing, in other words, Cohousing is not an answer to affordable housing at the moment. This type of housing scheme still needs more governmental and organizational support in the UK. In addition, 'Design Principles and Standards' and 'Sustainable Living' have been pointed out as two core determinants to affect people's motivations, social interactions and affordability (Fig. 5).

\section{Data display}

To better display the qualitative data, the study focused on the use of visuals to "amplify cognition." The visualisation data display method can well explain the interview data and efficiently show the dry data. As Fekete et al. (2008) found that the following advantages of using information visualisation method: 
- Increasing memory and processing resources available

- Reducing search for information

- Enhancing the recognition of patterns

- Enabling perceptual inference operations

- Using perceptual attention mechanisms for monitoring

- Encoding info in a manipulatable medium

\section{Figure $3 \& 4$ : Keywords refinement and word frequency statistics}

For each interview question, the number of black dots links to the opinions which are showing on the lower portion of the figure. The number showing in brackets means how many times of this opinion has been repeated for four interviewees in each group (e.g. (4) means four interviewees all mentioned this opinion). These opinions have been listed according to the number in the brackets, sorted from high to low. The answers have been divided into three categories by interviewees' attitudes: positive, neutral and negative.

\section{Figure 5 \& 6: Keywords analysis and mapping}

The figures show the key aspects of the answers, the attitude of the opinions (positive, neutral or negative) and the degree (grading) of the interviewees value these opinions.

\subsection{Views comparison}

According to the findings of step 5, the views comparison between architects and residents have been produced, which presents the similarity and difference between the two groups. This step addresses some design factors which have been neglected by the architects, shows the gaps and the new understanding of Cohousing living and also to identify what are the important drivers of the Cohousing design process. This comparison could be the valuable foundation to guide the design process for the architects and the current and future Cohousing groups.

\subsection{UK Sustainable Design Standards}

The following table lists the design standards which were pointed out during the interviews. This shows the following standards have been considered or applied in a Cohousing setting during the development process. The pros and cons have been discussed and summarised by the architects. This information could benefit more Cohousing group members by providing simple and clear information if the members hope to target low impact and lowcarbon community living. 
Wang, J., et.al. / Asian Journal of Behavioural Studies (AjBeS), 3(14) Nov / Dec 2018 (p.30-53)

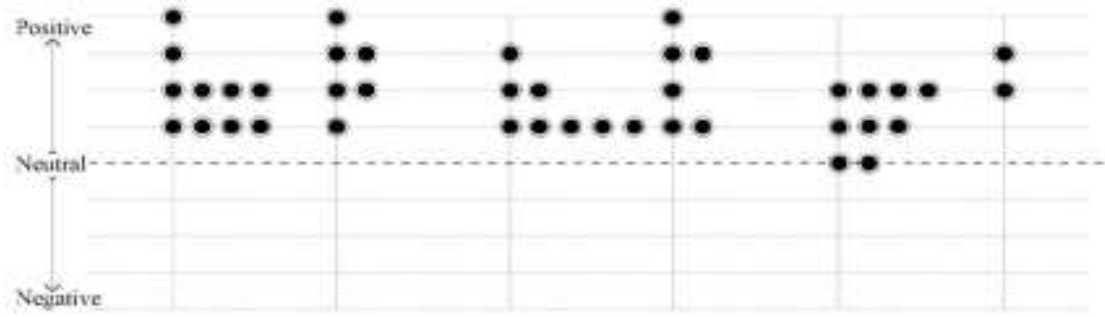

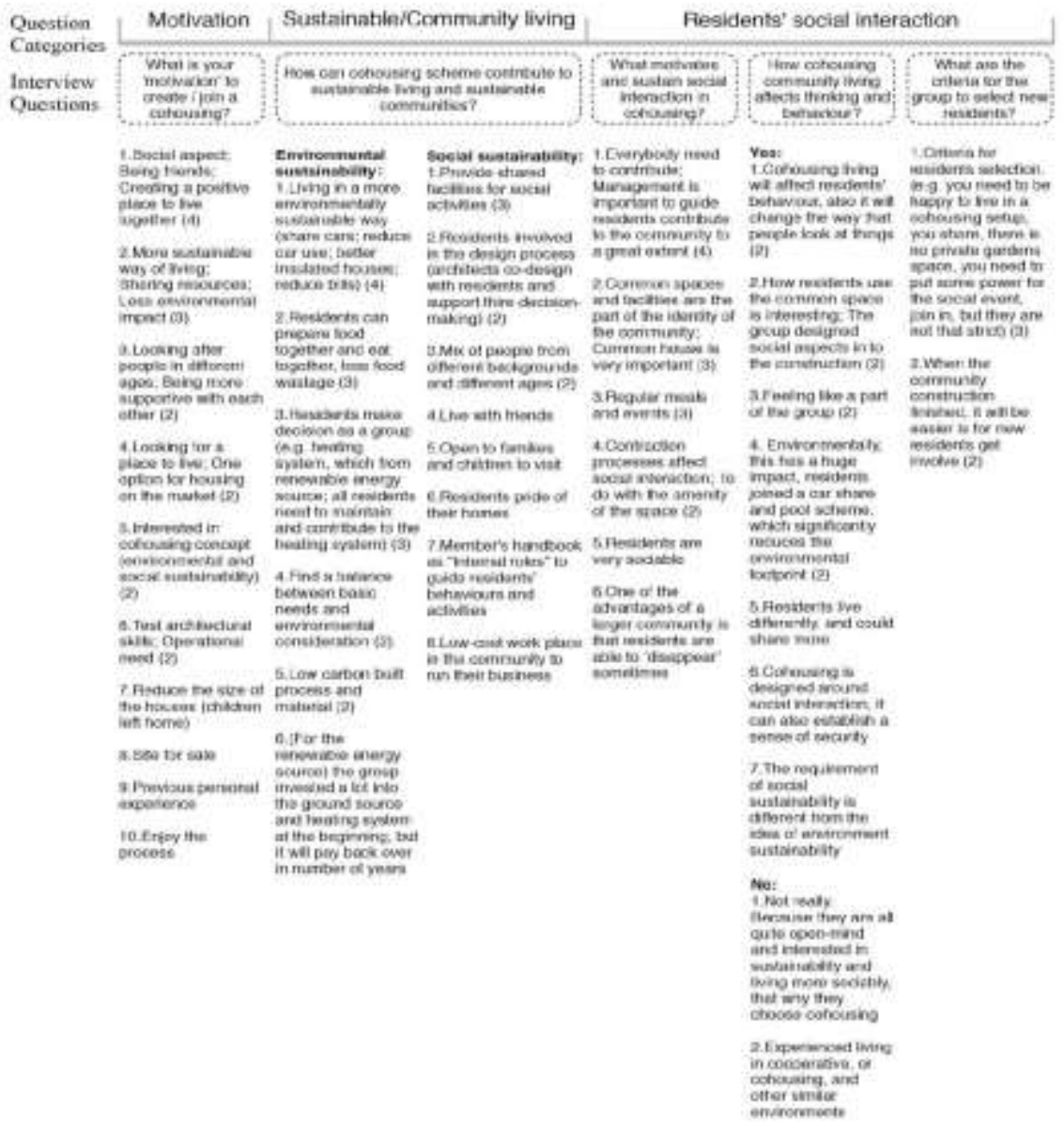

Fig.3 Keywords refinement and analysis (Architects).

(Source: authors) 


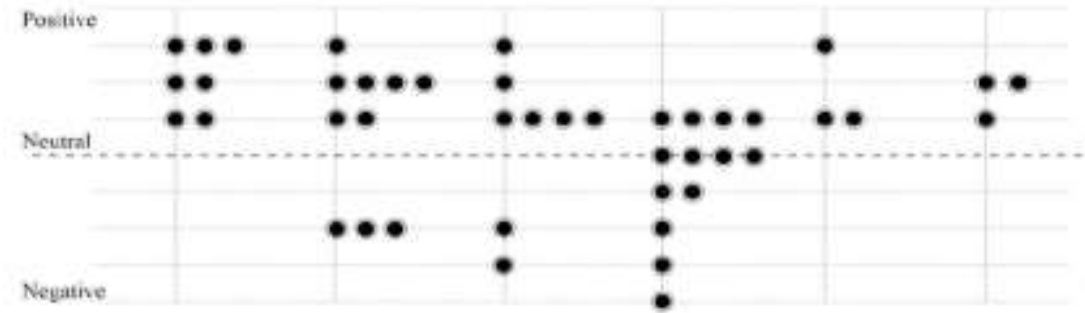

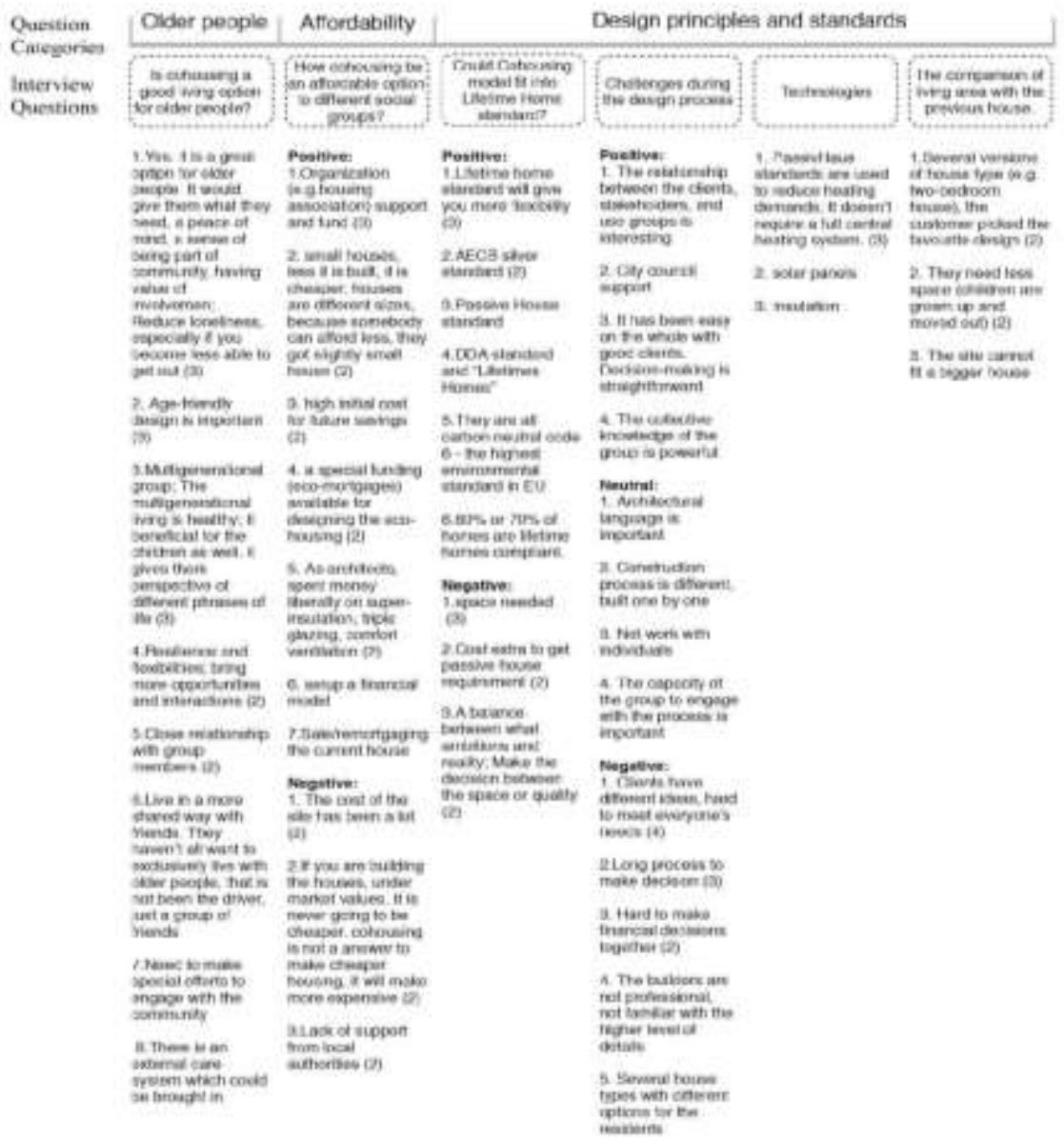

Fig.3 (continued) Keywords refinement and analysis (Architects).

(Source: authors) 
Wang, J., et.al. / Asian Journal of Behavioural Studies (AjBeS), 3(14) Nov / Dec 2018 (p.30-53)

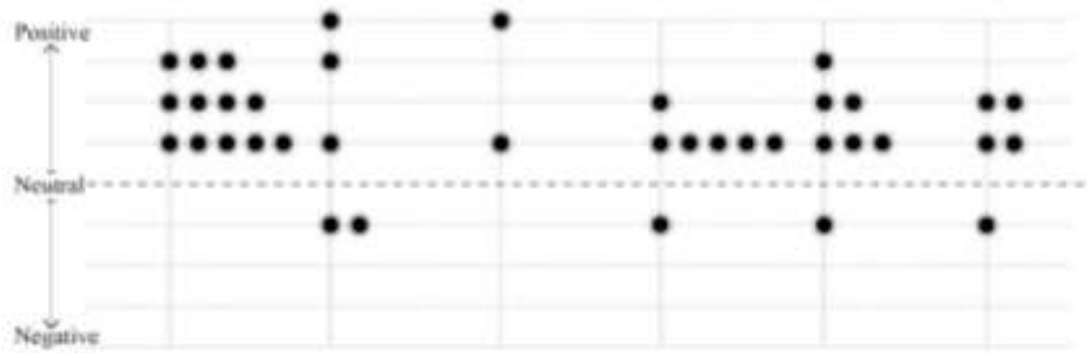

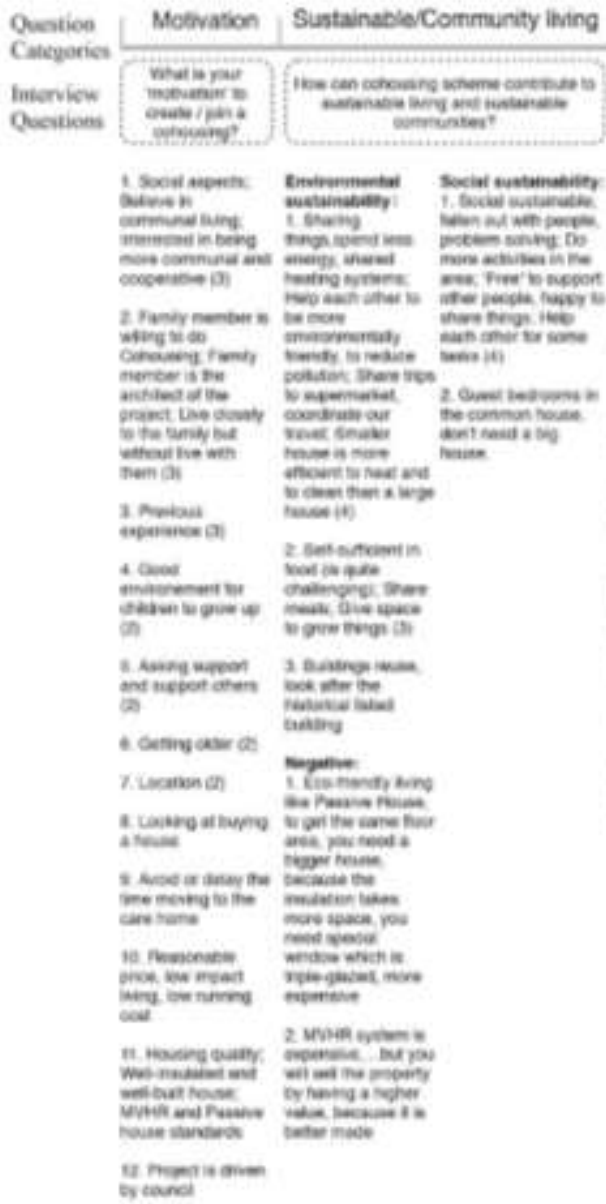

Residents' social interaction

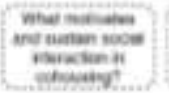

Hen anciaks

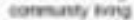

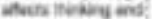
Itrovian:

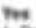

Puertive

1 Carmin wors

powa wa

argere (a)

2. Dongats

conter lagartur giath mone han is sing gents abore

2 kusty a noda eneary pace.

eretitim water an nons incherse

4 betents

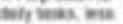
aer6 kr desh

5. Conanap

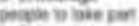
$n$ Cahouseng

Q A comency is

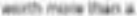
meftume hatus

\section{neyenes}

I C ing ons is

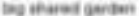
inets is étan. Eamianase commen sase

thesel

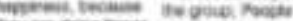

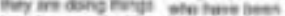

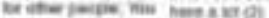
nonseves ahat is

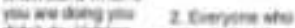

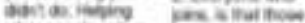

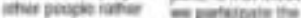

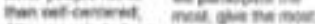

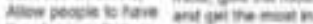

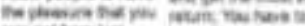

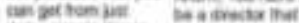

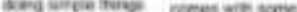

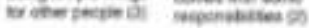

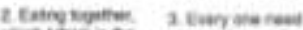

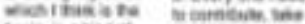

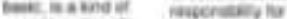

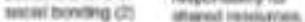
mus cekuran ar teae cuarom

3 kocetsery caribuake wit to pontowerime iknofy aren s. inwathes is ther nave orme ictor ask blewae $=$ and wert in bet as cok. if meare 2

4 Dusere tents. tharye as ine panses

5. To re weyery uefiah barkise in a sectervese ofiaben mai hass a mak. mare you yeneng moup non zo

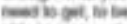
ate is catcerro. on afiar jowice

a Commen naves - enesen il Nime

wy:

1. There wethy

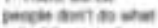
akas fom and weis mathare of te jecen gane the valla mes:

\section{Fig.4 Keywords refinement and analysis (Residents)}

(Source: authors) 
Wang, J., et.al. / Asian Journal of Behavioural Studies (AjBeS), 3(14) Nov / Dec 2018 (p.30-53)

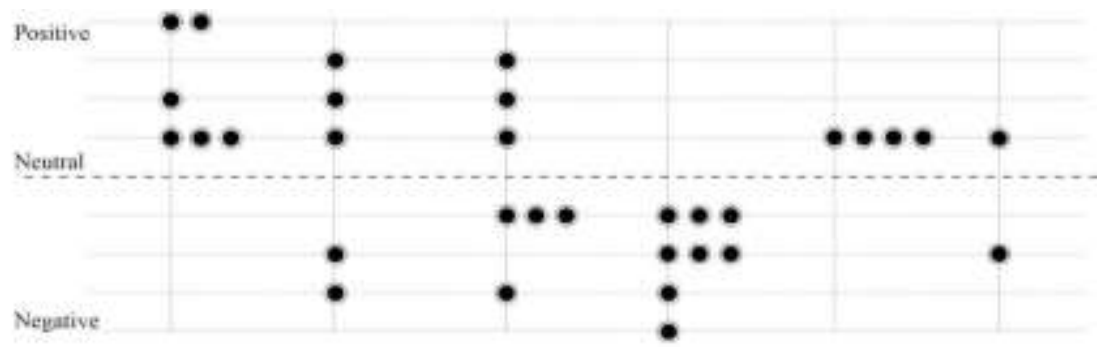

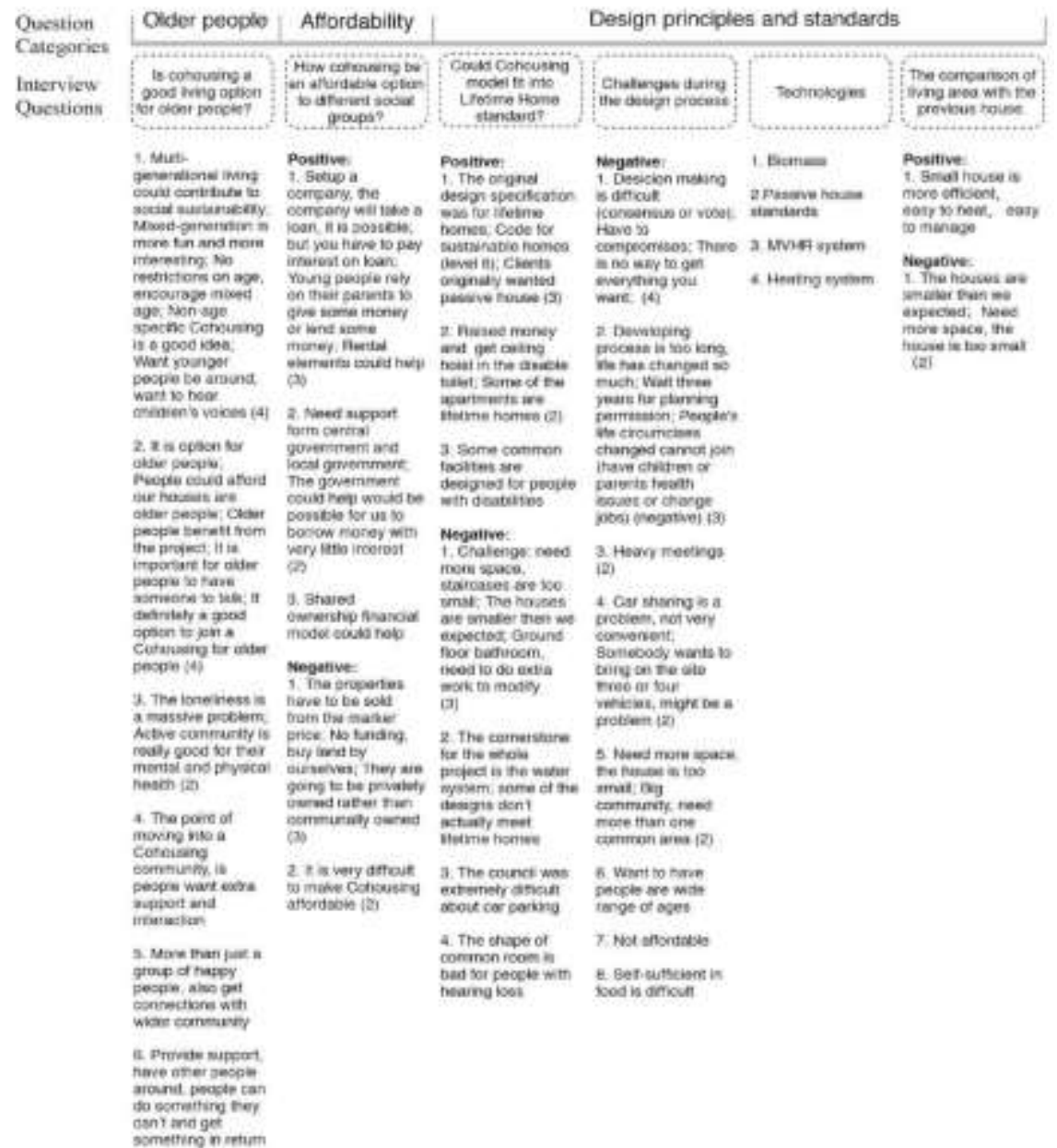

Fig.4 (continued) Keywords refinement and analysis (Residents). (Source: authors) 
Wang, J., et.al. / Asian Journal of Behavioural Studies (AjBeS), 3(14) Nov / Dec 2018 (p.30-53)
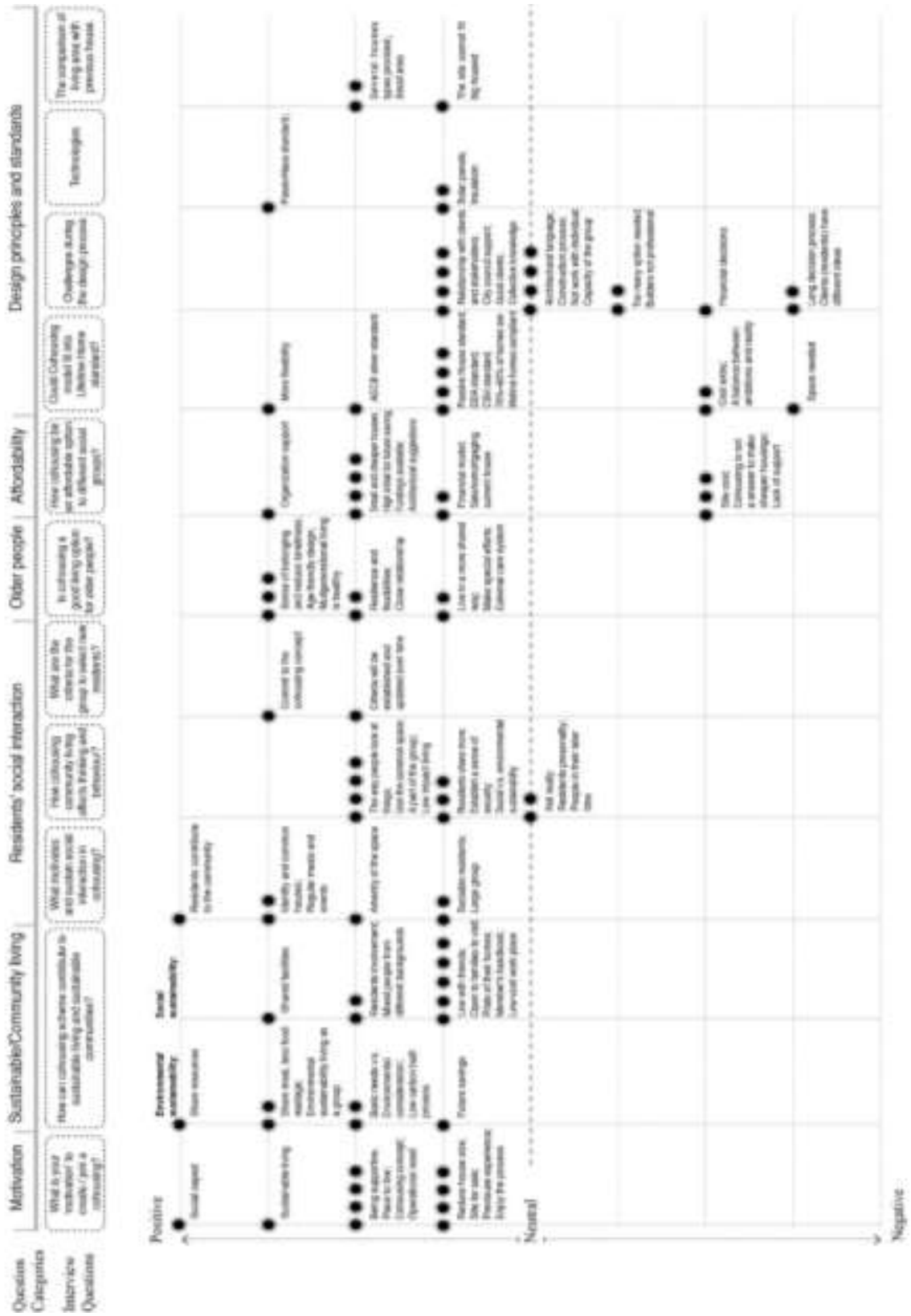

Fig 5: Keywords analysis and mapping (Architects).

(Source: authors) 

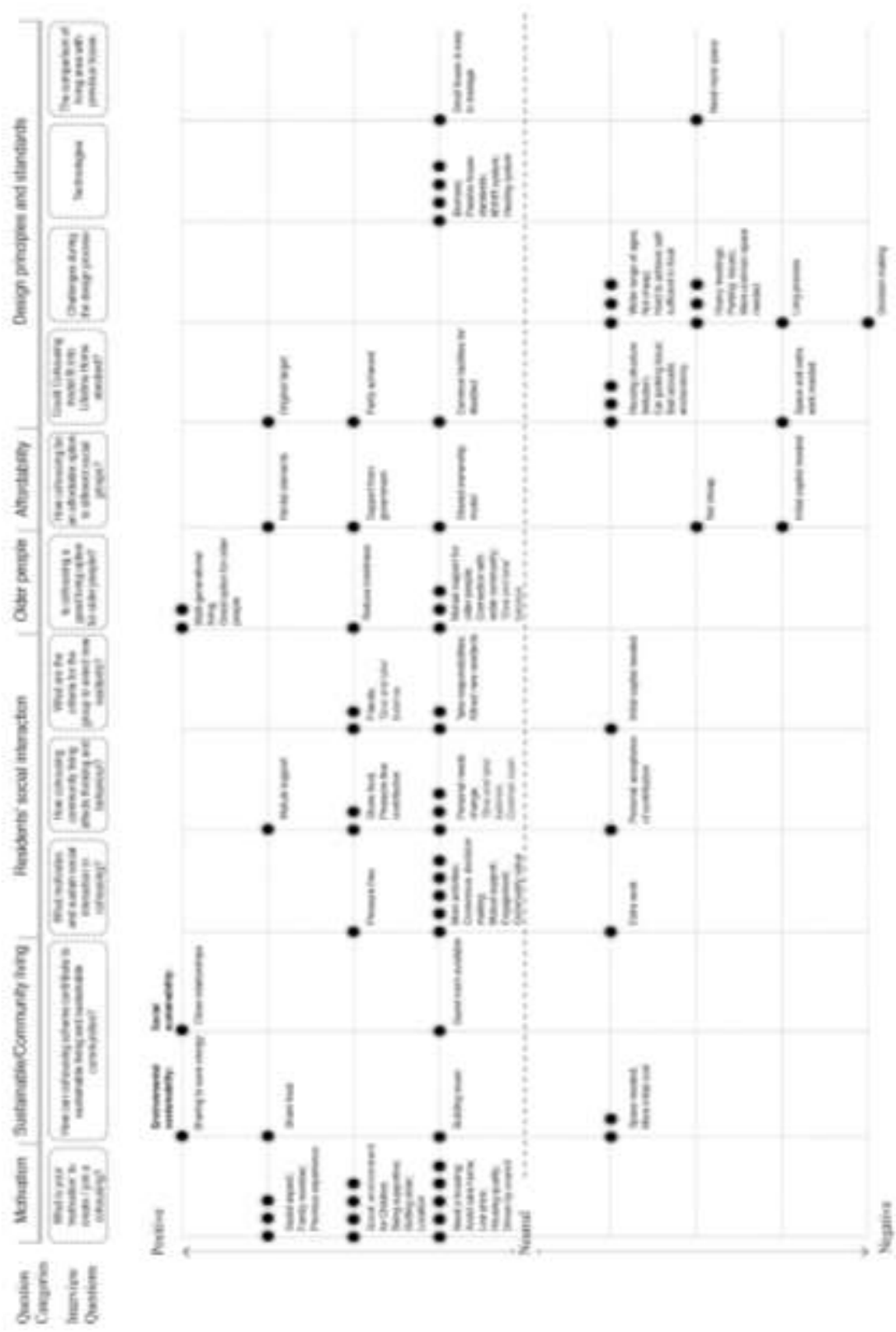

Fig 6: Keywords analysis and mapping (Residents).

(Source: authors) 
Table 2. Views Comparison (Architects VS Residents)

\begin{tabular}{|c|c|c|}
\hline Category & Architects Group & Residents Group \\
\hline \multirow[t]{2}{*}{ Motivation } & $\begin{array}{l}\text { Paid more attention to the cohousing } \\
\text { concept and features, they thought the } \\
\text { most important factor is the social aspect. }\end{array}$ & $\begin{array}{l}\text { Concentrated more on the housing itself, the } \\
\text { necessary physical condition of the house } \\
\text { (e.g.heating, insulation, location). In other } \\
\text { words, they focused on the housing itself and } \\
\text { then think about social aspects. }\end{array}$ \\
\hline & \multicolumn{2}{|c|}{$\begin{array}{l}\text { - Cohousing should be "cooperative + housing". } \\
\text {. Housing quality should be the foundation. }\end{array}$} \\
\hline \multirow[t]{2}{*}{$\begin{array}{l}\text { Sustainable/ } \\
\text { Community } \\
\text { living }\end{array}$} & $\begin{array}{l}\text { Cohousing could contribute a lot to } \\
\text { environmental and social sustainability, } \\
\text { including a series of extra dimensions, } \\
\text { such as the identity of the common house; } \\
\text { gather people from different backgrounds; } \\
\text { pride of their homes and residents } \\
\text { involvement. }\end{array}$ & Limitations of space and finance \\
\hline & \multicolumn{2}{|c|}{$\begin{array}{l}\text { - In environmental sustainability: save energy and share food; } \\
\text { - In social sustainability: close relationship,a good environment for children to grow up and } \\
\text { guest space. }\end{array}$} \\
\hline $\begin{array}{l}\text { Residents' } \\
\text { social } \\
\text { interaction }\end{array}$ & $\begin{array}{l}\text { Social interaction is a positive feature of a } \\
\text { cohousing community. }\end{array}$ & $\begin{array}{l}\text { There are negative aspects of social } \\
\text { interaction, such as heavy meetings and extra } \\
\text { work. "Give and take balance" and "pressure- } \\
\text { free environment" are necessary. }\end{array}$ \\
\hline Older people & $\begin{array}{l}\text { - Cohousing is a great option for the older } g \\
\text { - This type of living could reduce loneliness } \\
\text { - The Multi-generational living is better. }\end{array}$ & $\begin{array}{l}\text { eration. } \\
\text { a great extent. }\end{array}$ \\
\hline \multirow[t]{2}{*}{ Affordability } & $\begin{array}{l}\text { The capital is high, but it could be helpful } \\
\text { for future savings. }\end{array}$ & - \\
\hline & \multicolumn{2}{|c|}{$\begin{array}{l}\text { - Initial cost is high (e.g. advanced building technologies). } \\
\text { - Rental elements should be taken into consideration. } \\
\text { - Government support could be beneficial. }\end{array}$} \\
\hline \multirow[t]{2}{*}{$\begin{array}{l}\text { Design } \\
\text { principles } \\
\text { and } \\
\text { standards }\end{array}$} & $\begin{array}{l}\text { The closer relationship between architect } \\
\text { and residents is necessary and it has a } \\
\text { significant impact on the community } \\
\text { design. } \\
\text { - Prefer to work with the group rather than } \\
\text { individuals. }\end{array}$ & - \\
\hline & \multicolumn{2}{|l|}{ Making decisions as a group is very challenging. } \\
\hline
\end{tabular}

Table 3. Design Standards

$\begin{array}{lll}\text { Name of Design } & \text { Application } & \text { Pros and Cons } \\ \text { Standard } & \end{array}$

Lifetime Homes Standard Lifetime Homes are ordinary homes designed to incorporate sixteen Design Criteria that can be universally applied to new homes at minimal cost. Each design feature adds to the comfort and convenience of the home and supports the changing needs of individuals and
More circulation space needed, not fit well with the small house (-); More expensive (-); It gives a lot of flexibility. Especially for older people (+). 
families at different stages of life.

Lifetime Homes are all about flexibility and adaptability; they are not 'special' but are thoughtfully designed to create and encourage better living environments for everyone (The Lifetime Home Design Guide, 2010).

Association for
Environment Conscious
Building (AECB
Standard)

Association for Building (AECB Standard)
The AECB Building Standard is aimed at those wishing to create highperformance buildings using widely available technology at little or no extra cost. We estimate that this low-risk option will reduce overall $\mathrm{CO} 2$ emissions by $70 \%$ compared to the UK average for buildings of each type. Individual self-builders and large-scale residential and non-residential developers could make a valuable contribution to the low-carbon building by meeting the AECB Building Standard (AECB. n.d.).

\section{PassivHaus Standard}
PassivHaus or 'Passive House' is the fastest growing energy performance standard in the world with 30,000 buildings realised to date with the majority of those since the turn of the century. The PassivHaus standards strengths lie in the simplicity of its approach; build a house that has an excellent thermal performance, exceptional airtightness with mechanical ventilation.
This robust approach to building design allows the designer to minimise the 'Heating Demand' of the building and in some residential buildings only specify a heated towel rail as means of conventional heating; this heat can then be recovered and circulated by a Mechanical Ventilation and Heat Recovery (MVHR) unit (BRE. n.d).

Little or no extra cost (+); Apply to residential and nonresidential buildings (+); The Low-carbon building (+);

\author{
More investment required at the \\ beginning (-); \\ Good for future savings; Lower \\ running cost for the living space in \\ the future. e.g. less heating and \\ cooling cost (+);
}

\begin{tabular}{|c|c|c|}
\hline $\begin{array}{l}\text { Code for Sustainable } \\
\text { Homes (CSH) }\end{array}$ & $\begin{array}{l}\text { The Code for Sustainable Homes (the } \\
\text { Code) is an environmental assessment } \\
\text { method for rating and certifying the } \\
\text { performance of new homes. It is a } \\
\text { national standard for use in the design } \\
\text { and construction of new homes to } \\
\text { encouraging continuous improvement in }\end{array}$ & $\begin{array}{l}\text { More investment required at the } \\
\text { beginning (-); } \\
\text { Good for future savings (+); } \\
\text { Low-carbon (Zero-carbon) } \\
\text { emissions }(+)\end{array}$ \\
\hline
\end{tabular}


sustainable home building.

The Code for Sustainable Homes covers nine categories of sustainable design:

- Energy and $\mathrm{CO} 2$ Emissions $\cdot$ Water $•$

Materials • Surface Water Run-off • Waste $\cdot$ Pollution $\cdot$ Health and Wellbeing $\cdot$ Management $\cdot$ Ecology.

(Council, 2012)

Disability Discrimination Act (DDA Standard)
The Disability Discrimination Act 1995

(DDA) was introduced in 1996 and Part

III gave disabled people a right of

access to goods, facilities, services and

premises (Gawler, 2000).
Perfect for disabled people and

older people $(+)$

(Source: authors)

\subsection{Discussion and future research}

This paper aims to examine the main design principles, design priorities and challenges of Cohousing communities by exploring the design experiences of four Cohousing project architects and the living experience of four Cohousing residents. This research found some similarities and differences between the two groups. The following reasons could lead to the differences between the two groups:

1) Lack of space and financial support;

2) Personal needs change by time passes, residents understand themselves better by living closely with others. It still needs an in-depth understanding of "co" in the community and the residents' acceptance;

3) There is a gap between architects' initial scenario and reality.

From this study, design aspects and sustainable community living are two drivers which are primarily related to residents' motivation, social interactions and affordability. From the research findings, some actions may be required for the Cohousing design in the future:

1) Need more communication during the design process to understand residents' real needs. After residents move into the community, residents still need some supports from architect to use their home better and redesign the space;

2) Need more intervention within the community to improve the internal cooperation and connection, such as the design of the multi-functional common house.

The findings of this study highlight the focus, priorities, and challenges when designing a Cohousing community. It also identifies the limitations of current sustainable and lifetime design standards in the UK context.

A research gap has been identified which confirms that there is very little structured design knowledge and frameworks for physical and social settings to guide British Cohousing design development. Therefore, this paper could be an important reference to support 
cohousing design and also demonstrate a better understanding of new forms of community living in the UK. The limitations and drawbacks remain in this study, such as limited sample size. In addition, due to the differences of in the construction process and stages in Cohousing projects, it is tough to compare the design experiences between various Cohousing communities. Also, some architects who were involved in this study are also Cohousing members, and they designed the Cohousing community to suit their needs and other family members. There is no comparability to the architects who design the community for non-family clients.

According to Garciano (2011), the unique characteristics of a Cohousing neighbourhood, such as the intention to establish small houses and communities, the participatory planning process with residents and community-focused operations, may not always fit well in the current world of a Cohousing scheme and its funders. Its development may be influenced by several factors, such as personal experience, educational level, government policy, culture and underwriting criteria of public and private funders. "Resident participation in the development process is the Cohousing's greatest asset but also its most limiting factor. It is a huge task for a group of people inexperienced in both collective decision making and the building industry, to take on a project of this complexity. Most residents have little knowledge of financing, or design and construction for housing development" (McCamant \& Durrett, 1994, p.155). Cohousing can be an innovative community model to enhance residents' interaction with each other and with nature (Sangunietti, 2014). However, how can Cohousing models benefit wider society and the environment? Some Cohousing settlements in the UK showed better performance, such as LILAC project, Leeds. While, as Marckmann, et al. (2012) stated, the outcomes and developments are not unambiguously in favour of Cohousing, especially not compared with an average apartment building.

Cohousing communities use more sustainable technologies built into houses, but at the same time, the risk that technology would take up a disproportionate amount of maintenance time and energy (Marckmann et al. 2012). In other words, it is vital to keep the balance between having environmentally friendly technologies and what would be acceptable to residents. Usually, most environmental protection measures are linked to residents' behaviour. It will make this study data collection harder and also remains uncertain how the Cohousing scheme would work in a broader population. Finally, a long time is normally taken by the development process, where the group is seeking finance. This study will reduce development time and help to generate interest in these projects.

Compared with the literature review above, this study focuses on the design aspects of Cohousing community development. The findings of challenges facing Cohousing are listed below, which could be important information for future design work.

\section{Table 4. Challenges of Cohousing}

Design process

-Lifetime Home Standards does not always fit with small housing models. They require more circulation spaces.

-Achieving PassivHaus Standards may cost more at the beginning stage, but it is good for future savings and the environment.

- Parking space and car issues 
-Residents still need some support after they have moved in the community to use the space better.

\begin{tabular}{|c|c|}
\hline $\begin{array}{l}\text { Construction } \\
\text { process }\end{array}$ & $\begin{array}{l}\text { If the builders are not familiar with the higher level of building details or energy } \\
\text { performance. The construction process could be challenging. }\end{array}$ \\
\hline Affordability & $\begin{array}{l}\text { - It can be difficult to make financial decisions as a group. } \\
\text {-The land is expensive. Cohousing schemes are not the perfect answer for cheaper } \\
\text { housing. It needs lots of support from local authorities and organisations. } \\
\text {-Due to the financial reasons, it is difficult for young people to join a Cohousing group. } \\
\text {-If architects could spend more money on super-insulation, triple glazing, comfort } \\
\text { ventilation, and not spend money on complicated heating systems for space } \\
\text { heating and hot water. They could reduce the cost of renewable energy. This could } \\
\text { be very helpful. } \\
\text {-Achieving PassivHaus Standards may cost more at the beginning stage, but it is } \\
\left.\text { efficient for future savings and the environment. }{ }^{*}\right)\end{array}$ \\
\hline Social aspect & $\begin{array}{l}\text { - Give and take balance } \\
\text { - Pressure-free community living needs to be addressed } \\
\text { People have different ideas and views. If architects work with individuals to design their } \\
\text { private living units, the decision-making process takes much longer. } \\
\text {-There are usually very intense group meetings during the development process. }\end{array}$ \\
\hline
\end{tabular}

$\left.{ }^{*}\right)$ repeated point

(Source: authors)

Future research will concentrate more on how physical design settings affect residents' social interaction and behaviour. Also, how to build age-friendly environments for older residents who live in Cohousing communities. In addition, the future study will focus on the perceptions, needs and expectations of residents to counter the opinions of architects. The architects, designers and Cohousing group members could better weigh determinants which have been found in this study and also consider how to manage significant Cohousing challenges and limitations during the development process.

\subsection{Conclusion}

This research examined the Cohousing model by focussing on physical design and social aspects and providing a better understanding of the design principles, design standards, priorities and challenges of the Cohousing communities development process. The comparison between four architects' Cohousing design experience has highlighted the strengths and weaknesses of the Cohousing development procedure. The findings also highlighted that Cohousing could be an option for older people to achieve ageing-in-place. Additionally, the research is able to show the limitations of the cohousing model and to provide sustainability and affordability guidance for Cohousing designs. At the same time, the Cohousing study could potentially become a milestone for the evolution of housing provision, leading to the change of people's thinking and behaviour.

The findings of this study could be a useful tool to develop sustainable community 
building and could benefit a wide range of stakeholders. It could also potentially be applied to different settings and environments in the UK and beyond, accelerating the implementation of environmentally friendly homes and sustainable communities.

\section{Acknowledgement}

We would like to acknowledge the support offered by eight interviewees. We also appreciate the support given by Cambridge K1 Cohousing group, Sheffield Open House Project, Sheffield Shirle Hill Cohousing and Lancaster Cohousing group.

\section{References}

AECB standard. (n.d). Retrieved May 5, 2018, from https://www.aecb.net/carbonlite/carbonlite-programme/energyperformance-standards/

Allen, C., Milner, J., \& Price, D. (2002). Home is where the start is: the housing and urban experiences of visually impaired children. Policy Press.

Berggren, H. M. (2017). Cohousing as Civic Society: Cohousing Involvement and Political Participation in the United States. Social Science Quarterly, 98(1), 57-72.

BRE. (n.d). PassivHaus Standard. Retrieved May 9, 2018, from https://www.bre.co.uk/page.jsp?id=2856

Canadian Cohousing Network. (2018). What is cohousing? Retrieved May 25, 2018, from http://cohousing.ca/whatis-cohousing/

Council, W. L. B. (2012). Code for Sustainable Homes. Retrieved May 6, 2018, from https://assets.publishing.service.gov.uk/government/uploads/system/uploads/attachment_data/file/5976/code_for_ sustainable_homes_techguide.pdf

Dempsey, N., Bramley, G., Power, S., \& Brown, C. (2009). The social dimension of sustainable development: Defining urban social sustainability. Sustainable Development. Vol.19, 289-300.

Fekete, J. D., Van Wijk, J. J., Stasko, J. T., \& North, C. (2008). The value of information visualization. In Information visualization (pp. 1-18). Springer, Berlin, Heidelberg.

Fromm, D. (2000). American Cohousing: The First Five Years. Journal of Architectural and Planning Research, Vol.17, 94-109.

Garciano, J. L. (2011). Affordable Cohousing: Challenges and Opportunities for Supportive Relational Networks in Mixed-Income Housing. Journal of Affordable Housing \& Community Development Law, 20(2), 169-192.

Gawler, T. O. (2000). Disability Discrimination Act. Retrieved May 10, 2018, from http://citeseerx.ist.psu.edu/viewdoc/download?doi=10.1.1.348.3380\&rep=rep1\&type=pdf

Housing LIN. (2008). The cohousing approach to 'Lifetime Neighbourhoods'. Department of Health. Retrieved May 14, 2018, from https://www.housinglin.org.uk/Topics/type/The-Cohousing-Approach-to-Lifetime-Neighbourhoods/

Imrie, R. (2006). Independent lives and the relevance of lifetime homes. Disability \& Society. 21(4), 359-374. 
Jarvis, H., Scanlon, K., Fernandez Arrigoitia, M., Chatterton, P., Kear, A., O'Reilly, D. G., .. \& Stevenson, F. (2016). Cohousing: shared futures.

Kelly, M. (2001). Lifetime home, in: S. Peace \& C. Holland (Eds.), Inclusive housing in an ageing society, Bristol, Policy Press, 55-76.

Lehtonen, M. (2004). The environmental-social interface of sustainable development: capabilities, social capital, institutions. Ecological economics, 49(2), 199-214.

Lietaert, M. (2010). Cohousing's relevance to degrowth theories. Journal of Cleaner Production, 18(6), 576-580.

Lifetime Homes. (2010). Lifetime Homes 16 Design Criteria. Retrieved May 1, 2018, from http://www.lifetimehomes.org.uk/pages/design-criteria.html

Lister, R. (2000). Strategies for social inclusion: promoting social cohesion or social justice? In Social Inclusion: Possibilities and Tensions, Askonas, P., Stewart, A. Macmillan: Basingstoke; 37-54.

Marckmann, B., Gram-Hanssen, K., \& Christensen, T. H. (2012). Sustainable living and co-housing: evidence from a case study of eco-villages. Built Environment, 38(3), 413-429.

McCamant, K., \& Durrett, C. (1994). Cohousing. A Contemporary Approach to Housing Ourselves, 2.

Morrison, J. (2013). A future for affordable housing: Can cohousing ne a viable model for delivering affordable housing in the UK? (Master thesis), The University of Sheffield, Sheffield, UK.

Petty, N. J. Thomson, O. P., \& Stew, G. (2012). Ready for a paradigm shift? Part 2: Introducing qualitative research methodologies and methods. Manual therapy, 17(5), 378-384.

Priest, I. (2015). Different kind of living. RIBA Journal, 122(10), 54.

Ruiu, M. L. (2014). Differences between Cohousing and Gated Communities: A Literature Review. Sociological Inquiry, 84(2), 316-335.

Ruiu, M. L. (2016). Participatory processes in designing cohousing communities: the case of the community project. Housing and Society, 43(3), 168-181.

Sanguinetti, A. (2014). Transformational practices in cohousing: Enhancing residents' connection to community and nature. Journal of Environmental Psychology, 40, 86-96.

Sargisson, L. (2012). Second-wave cohousing: a modern Utopia?. Utopian Studies, 23(1), 28-56.

Silverman, D. (Ed.). (2016). Qualitative research. Sage.

Strauss, A., \& Corbin, J. (1998). Basics of Qualitative Research, 2nd ed. London: SAGE Publications, Inc.

Stern, P.N. (1980). Grounded theory methodology: Its uses and processes.

The Young Foundation. (2010). Never Again-Avoiding the mistakes of the past, London.

UK Cohousing Network. (2018). Cohousing in the UK. Retrieved April 24, 2018, from http://cohousing.org.uk/cohousing-uk

Wang J., Hadjri, Karim, Morris, D. \& Bennett S. (2016). The role of cohousing in social communication and 
Wang, J., et.al. / Asian Journal of Behavioural Studies (AjBeS), 3(14) Nov / Dec 2018 (p.30-53)

sustainable living environments. Third \{OIKONET\} Conference, University of Central Lancashire, Vol. 23

Williams, J. (2005). "Designing Neighbourhoods for Social Interaction: The Case of Cohousing", Journal of Urban Design, 10(2), 195-227. 